\title{
Application of the Theory of Micropolar Continuum on the Flow Suspension in a Cylindrical Channel
}

Associate -Professor University of Belgrade

Faculty of Forestry

D. Salemović

High Technical School Zrenjanin Department for Mechanical Engineering

\section{B. Jovanović}

Full Professor University of Belgrade Mathematical Faculty
This paper presents an analytical solution of a mathematical model which treats fluid flow suspension in a cylindrical channel. The model is the application of the theory of micropolar continuum on the flow of suspension and it consists of coupled linear differential equations with variable coefficients. The cylindrical channel consists of two cylinders: the internal cylinder was still and the external one rotated with constant velocity. This model enabled us to analyze the motion of a suspension, as heterogeneous mixture of a liquid with solid particles. The solution was found in the form of special Bessel's functions of the zero and the first order. The results were shown on diagrams for some characteristic values, and the good agreement was achieved between the calculated and expected results.

Keywords: suspension, fluid flow, cylindrical channel, analytical solution, Bessel's functions.

\section{INTRODUCTION}

The stress-strain situations in the classical continuum mechanics are usually described by means of a symmetric stress tensor. Unfortunately, the classical continuum model was not sufficient for the description of the behavior of certain mixtures, such as: suspensions, liquid crystals, fluid transport of porous granular materials, etc. That was the reason why the continuum model with microstructure was introduced [1].

Eringen and Suhubi [2] introduced the micropolar continuum followed by micropolar fluid models characterized by the couple stress and a nonsymmetrical stress tensor. The theory and its applications were later developed in [3] and [4]. This theory comprises two independent kinematic quantities: the velocity vector and the microrotation vector. The micropolar model can, among other applications such as at composite materials [5], be used to describe the motion of suspension as a mixture of two phases [6-10]. The basic phase of the suspension is a fluid, whereas the dispersive phase consists of solid particles. The description of microchannel fluid behavior using a numerical model based on micropolar fluid theory was explained in paper [11]. The transient heat convection phenomena of micropolar fluids flowing through wavy channels saturated with porous media were analyzed in [12] and [13]. The effects of the physical parameters on the velocity and microrotation vector were investigated in [14]. The paper [15] proved the presence of an $\mathrm{H}_{2}$ global attractor and in that way the existence of a solution of the micropolar model.

Received: April 2016, Accepted: September 2016

Correspondence to: Dr Aleksandar Dedić

Faculty of Forestry, Kneza Višeslava 1, 11030

Belgrade, Serbia

E-mail: aleksandar.dedic@sfb.bg.ac.rs

doi:10.5937/fmet1701103D

(C) Faculty of Mechanical Engineering, Belgrade. All rights reserved
In order to describe the behavior of the suspension, two coupled differential equations were introduced in this paper. As the system involves coupled equations, the Method of Frobenius that can be applied to common differential equations was not applicable. That is why the aim of this paper was to solve the coupled system and do not lose the point of micropolar continuum. It was achieved to get the solution in the closed analytical form. In that way, the velocity $v(r)$ and the microrotational velocity $w(r)$ were represented by modified Bessel functions of the zero and the first order.

\section{THE MATHEMATICAL MODEL}

The physical interpretation of the model is shown in Figure 1.

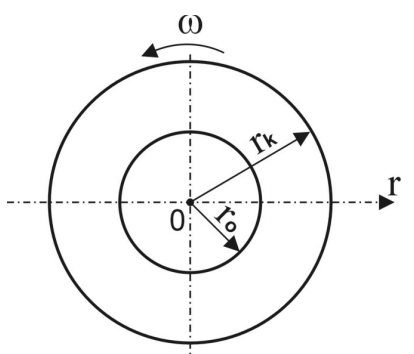

Figure 1. A simplified functional diagram of the movement of the suspension between two coaxial cylinders

Two coaxial cylinders: the inner one, which is stationary, and the outer rotating one with constant angular velocity $(\omega)$, while the suspension of certain physical properties moves between them. In this way, each solid particle obtains two components of speed: the unknown velocity of the suspension (macromotion) $(v)$ and the unknown velocity of solid particles in the suspension (microrotation) $(w)$. Radius of the internal cylinder is $r_{o}$ and radius of the external cylinder is $r_{k}$.

The mathematical model of the flow of suspension, describing the velocity field $(v)$ of the movement of the 
suspension and the velocity field of the microrotation of the suspension $(w)$, depending on the radial coordinate $(r)$ and defined by a coupled system of two ordinary linear differential equations of the second order with variable coefficients, which have the following form [16]:

$r^{2} \frac{d^{2} v}{d r^{2}}+r \frac{d v}{d r}-v-\frac{\alpha_{1}}{1+\alpha_{1}} r^{2} \frac{d w}{d r}=0$,

$\alpha_{2} r \frac{d v}{d r}+\alpha_{2} v+r \frac{d^{2} w}{d r^{2}}+\frac{d w}{d r}-2 \alpha_{2} r w=0$.

where $\alpha_{1}=$ const $>0$ and $\alpha_{2}=$ const $>0$ which denote the viscosity coefficients of the micropolar continuum.

Boundary conditions for the equations (1) and (2) are:

$$
\begin{aligned}
& \left.v(r)\right|_{r=r_{0}}=v\left(r_{0}\right)=v_{0}=0, \\
& \left.v(r)\right|_{r=r_{k}}=v\left(r_{k}\right)=v_{k}=r_{k} \omega, \\
& \left.w(r)\right|_{r=r_{0}}=w\left(r_{0}\right)=w_{0}=0, \\
& \left.w(r)\right|_{r=r_{k}}=w\left(r_{k}\right)=w_{k}=0 .
\end{aligned}
$$

Boundary contours at which the system of equations (1) and (2) with boundary conditions (3), (4), (5) and (6) are valid are along the radial coordinate $(r)$ and in the range from the internal $\left(r_{o}\right)$ to the outer $\left(r_{k}\right)$ radius, as shown in Figure 2.

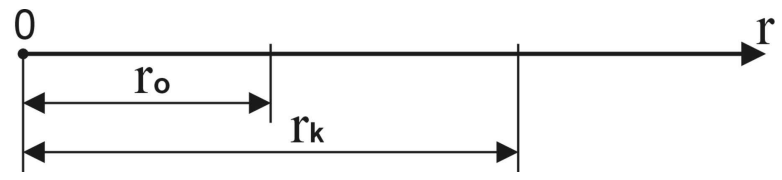

Figure 2. Boundary contours for the system of equations (1) and (2) with the boundary conditions (3), (4), (5) and (6)

\section{SOLUTION OF THE PROBLEM}

From the equation (1) follows:

$$
\begin{aligned}
& \frac{\alpha_{1}}{1+\alpha_{1}} \cdot \frac{d w}{d r}=\frac{d^{2} v}{d r^{2}}+\frac{1}{r} \cdot \frac{d v}{d r}-\frac{v}{r^{2}}, \\
& \frac{\alpha_{1}}{1+\alpha_{1}} \cdot \frac{d w}{d r}=\frac{d}{d r}\left(\frac{d v}{d r}+\frac{v}{r}\right),
\end{aligned}
$$

Using direct integration of the equation (8), we get:

$$
\frac{\alpha_{1}}{1+\alpha_{1}} \cdot w=\frac{d v}{d r}+\frac{v}{r}+C_{1}
$$

where $\left(C_{1}\right)$ is a constant and it will be determined later.

From equation (2) follows:

$$
\alpha_{2} r\left(\frac{d v}{d r}+\frac{v}{r}\right)+r \frac{d^{2} w}{d r^{2}}+\frac{d w}{d r}-2 \alpha_{2} r w=0 .
$$

Substituting a part of equation (10) with (9) will be followed by:

$$
\begin{aligned}
& \alpha_{2} r\left(\frac{\alpha_{1}}{1+\alpha_{1}} w-C_{1}\right)+r \frac{d^{2} w}{d r^{2}}+\frac{d w}{d r}-2 \alpha_{2} r w=0, \\
& r \frac{d^{2} w}{d r^{2}}+\frac{d w}{d r}+\alpha_{2}\left(\frac{\alpha_{1}}{1+\alpha_{1}}-2\right) \cdot r w=\alpha_{2} C_{1} r .
\end{aligned}
$$

In the end, it was obtained:

$$
r \frac{d^{2} w}{d r^{2}}+\frac{d w}{d r}-\alpha_{2} \frac{2+\alpha_{1}}{1+\alpha_{1}} r w=\alpha_{2} C_{1} r .
$$

If a new constant will be introduced, defined by the following expression:

$$
\beta=-\alpha_{2} \frac{2+\alpha_{1}}{1+\alpha_{1}}
$$

the equation (13) becomes:

$$
r \frac{d^{2} w}{d r^{2}}+\frac{d w}{d r}+\beta r w=\alpha_{2} C_{1} r
$$

A general solution of the homogeneous part of the equation:

$$
r \frac{d^{2} w}{d r^{2}}+\left(\frac{d w}{d r}+\beta r w=0\right.
$$

Can be represented by a cylindrical function of the zero order:

$$
w_{h}(r)=Z_{o}(\sqrt{\beta} r)=C_{3} J_{0}(\sqrt{\beta} r)+C_{4} Y_{0}(\sqrt{\beta} r)
$$

In the above expression (17), the zero-order Bessel function was introduced, which is defined as:

$$
J_{0}(x)=\sum_{k=0}^{\infty} \frac{(-1)^{k}}{(k !)^{2}}\left(\frac{x}{2}\right)^{2 k}
$$

while $\left(Y_{0}\right)$ marked the associated zero-order Bessel function, which is defined as:

$$
Y_{0}(x)=\frac{2}{\pi} J_{0}(x) \ln \left(\frac{e^{\gamma} x}{2}\right)-\frac{2}{\pi} \sum_{k=0}^{\infty} \frac{(-1)^{k}}{(k !)^{2}}\left(\sum_{j=1}^{k} \frac{1}{j}\right)\left(\frac{x}{2}\right)^{(2 k)}
$$

Here $(\gamma)$ denoted the Euler constant, as follows:

$$
\gamma=0,577215665
$$

while $\left(C_{3}\right)$ and $\left(C_{4}\right)$ denoted the arbitrary constants.

It is easy to confirm that equation (15) has a particular solution in the form of a constant:

$$
w_{p}(r)=C_{1} \frac{1+\alpha_{1}}{2+\alpha_{1}}
$$

The solution of equation (15) can be represented as the sum of particular solution and the general solution of homogeneous equation:

$$
\begin{aligned}
& w_{p}(r)=C_{1} \frac{1+\alpha_{1}}{2+\alpha_{1}} \\
& w(r)=C_{3} J_{0}(\sqrt{\beta} r)+C_{4} Y_{0}(\sqrt{\beta} r)-C_{1} \frac{1+\alpha_{1}}{2+\alpha_{1}}
\end{aligned}
$$

Constants $\left(C_{3}\right)$ and $\left(C_{4}\right)$ are determined from boundary conditions (5) and (6), as:

$$
w\left(r_{0}\right)=C_{3} J_{0}\left(\sqrt{\beta} r_{0}\right)+C_{4} Y_{0}\left(\sqrt{\beta} r_{0}\right)-C_{1} \frac{1+\alpha_{1}}{2+\alpha_{1}}=0(24)
$$


$w\left(r_{k}\right)=C_{3} J_{0}\left(\sqrt{\beta} r_{k}\right)+C_{4} Y_{0}\left(\sqrt{\beta} r_{k}\right)-C_{1} \frac{1+\alpha_{1}}{2+\alpha_{1}}=0$

$C_{3}=C_{1} \frac{1+\alpha_{1}}{2+\alpha_{1}} \cdot \frac{Y_{0}\left(\sqrt{\beta} r_{k}\right) \cdot Y_{0}\left(\sqrt{\beta} r_{0}\right)}{D}$

$C_{4}=C_{1} \frac{1+\alpha_{1}}{2+\alpha_{1}} \cdot \frac{J_{0}\left(\sqrt{\beta} r_{0}\right) \cdot J_{0}\left(\sqrt{\beta} r_{k}\right)}{D}$

where:

$D=J_{0}\left(\sqrt{\beta} r_{0}\right) \cdot Y_{0}\left(\sqrt{\beta} r_{k}\right)-J_{0}\left(\sqrt{\beta} r_{k}\right) \cdot Y_{0}\left(\sqrt{\beta} r_{0}\right)$

Inserting of expression (23) into (9) will be followed by:

$$
\frac{d v}{d r}+\frac{v}{r}=\frac{\alpha_{1}}{1+\alpha_{1}} \cdot\left[C_{3} J_{0}(\sqrt{\beta} r)+C_{4} Y_{0}(\sqrt{\beta} r)\right]-2 C_{1} \frac{1+\alpha_{1}}{2+\alpha_{1}} .
$$

The general solution of the above equation, as follows:

$$
v(r)=\frac{1}{r}\left(C_{2}+\frac{\alpha_{1}}{1+\alpha_{1}} \cdot A-C_{1} \frac{1+\alpha_{1}}{2+\alpha_{1}} r^{2}\right),
$$

where:

$$
A=C_{3} \int r J_{0}(\sqrt{\beta} r) d r+C_{4} \int r Y_{0}(\sqrt{\beta} r) d r
$$

Let's introdudce the relations:

$$
\begin{aligned}
& \int x J_{0}(x) d x=x J_{1}(x)+\text { const } \\
& \int x Y_{0}(x) d x=x Y_{1}(x)+\text { const }
\end{aligned}
$$

where $\left(J_{1}\right)$ denoted the first order Bessel function:

$$
J_{1}(x)=\sum_{k=0}^{\infty} \frac{(-1)^{k}}{k !(k+1) !} \cdot\left(\frac{x}{2}\right)^{(2 k+1)}
$$

and $\left(Y_{1}\right)$ the associated Bessel function of the first order:

$$
\begin{aligned}
& Y_{1}(x)=\frac{2}{\pi} J_{1}(x) \ln \left(\frac{e^{\gamma} x}{2}\right)-\frac{2}{\pi x}- \\
& -\frac{2}{\pi} \sum_{k=0}^{\infty} \frac{(-1)^{k}}{k !(k+1) !}\left(\sum_{j=1}^{k} \frac{1}{j}+\frac{1}{2 k+2}\right) \cdot\left(\frac{x}{2}\right)^{(2 k+1)}
\end{aligned}
$$

Equation (30) can be further transformed as follows:

$$
\begin{aligned}
& v(r)=\frac{C_{2}}{r}+\frac{\alpha_{1}}{1+\alpha_{1}} \cdot \frac{1}{\beta} \cdot \frac{1}{r} \cdot\left(C_{3} \sqrt{\beta} r J_{1}(\sqrt{\beta} r)+\right. \\
& \left.+C_{4} \sqrt{\beta} r Y_{1}(\sqrt{\beta} r)\right)-C_{1} \frac{1+\alpha_{1}}{2+\alpha_{1}} r .
\end{aligned}
$$

It should be noted that constant $\left(C_{2}\right)$ already comprises integration constants that appear in expressions (32) and (33).

Given expression (14), expression (36) takes the following form:

$$
\begin{aligned}
& v(r)=\frac{C_{2}}{r}-\frac{\alpha_{1}}{\alpha_{2}} \cdot \frac{\sqrt{\beta}}{2+\alpha_{1}} \cdot\left(C_{3} J_{1}(\sqrt{\beta} r)+\right. \\
& \left.+C_{4} Y_{1}(\sqrt{\beta} r)\right)-C_{1} \frac{1+\alpha_{1}}{2+\alpha_{1}} r .
\end{aligned}
$$

Finally, taking into account expressions (26) and (27), the previous expression takes the final form:

$$
\begin{aligned}
& v(r)=\frac{C_{2}}{r}-C_{1} \frac{\alpha_{1}\left(1+\alpha_{1}\right)}{\alpha_{2}\left(2+\alpha_{1}\right)^{2}} . \\
& \frac{Y_{0}\left(\sqrt{\beta} r_{k}\right)-Y_{0}\left(\sqrt{\beta} r_{0}\right)}{D} \cdot \sqrt{\beta} J_{1}(\sqrt{\beta} r)- \\
& -C_{1} \frac{\alpha_{1}\left(1+\alpha_{1}\right)}{\alpha_{2}\left(2+\alpha_{1}\right)^{2}} \cdot \frac{J_{0}\left(\sqrt{\beta} r_{0}\right)-J_{0}\left(\sqrt{\beta} r_{k}\right)}{D} . \\
& \cdot \sqrt{\beta} Y_{1}(\sqrt{\beta} r)-C_{1} \frac{1+\alpha_{1}}{2+\alpha_{1}} r .
\end{aligned}
$$

Constants $\left(C_{1}\right)$ and $\left(C_{2}\right)$ are determined from boundary conditions (3) and (4), respectively:

$$
\begin{aligned}
& v\left(r_{0}\right)=\frac{C_{2}}{r_{0}}-C_{1} \frac{\alpha_{1}\left(1+\alpha_{1}\right)}{\alpha_{2}\left(2+\alpha_{1}\right)^{2}} . \\
& \frac{Y_{0}\left(\sqrt{\beta} r_{k}\right)-Y_{0}\left(\sqrt{\beta} r_{0}\right)}{D} \cdot \sqrt{\beta} J_{1}\left(\sqrt{\beta} r_{0}\right)- \\
& -C_{1} \frac{\alpha_{1}\left(1+\alpha_{1}\right)}{\alpha_{2}\left(2+\alpha_{1}\right)^{2}} \cdot \frac{J_{0}\left(\sqrt{\beta} r_{0}\right)-J_{0}\left(\sqrt{\beta} r_{k}\right)}{D} . \\
& \cdot \sqrt{\beta} Y_{1}\left(\sqrt{\beta} r_{0}\right)-C_{1} \frac{1+\alpha_{1}}{2+\alpha_{1}} r_{0}=0 . \\
& v\left(r_{k}\right)=\frac{C_{2}}{r_{k}}-C_{1} \frac{\alpha_{1}\left(1+\alpha_{1}\right)}{\alpha_{2}\left(2+\alpha_{1}\right)^{2}} . \\
& \cdot \frac{Y_{0}\left(\sqrt{\beta} r_{k}\right)-Y_{0}\left(\sqrt{\beta} r_{0}\right)}{D} \cdot \sqrt{\beta} J_{1}\left(\sqrt{\beta} r_{k}\right) \\
& -C_{1} \frac{\alpha_{1}\left(1+\alpha_{1}\right)}{\alpha_{2}\left(2+\alpha_{1}\right)^{2}} \cdot \frac{J_{0}\left(\sqrt{\beta} r_{0}\right)-J_{0}\left(\sqrt{\beta} r_{k}\right)}{D} . \\
& \sqrt{\beta} Y_{1}\left(\sqrt{\beta} r_{k}\right)-C_{1} \frac{1+\alpha_{1}}{2+\alpha_{1}} r_{k}=r_{k} \omega .
\end{aligned}
$$

This implies

$$
\begin{aligned}
& C_{1}=\frac{r_{k}^{2} \omega \alpha_{2}\left(2+\alpha_{1}\right)^{2} D}{\alpha_{1}\left(1+\alpha_{1}\right)} \cdot\left\{\frac{\alpha_{2}\left(2+\alpha_{1}\right) D}{\alpha_{1}}\left(r_{0}^{2}-r_{k}^{2}\right)+\right. \\
& +\left[Y_{0}\left(\sqrt{\beta} r_{0}\right)-Y_{0}\left(\sqrt{\beta} r_{k}\right)\right] . \\
& \cdot\left[\sqrt{\beta} r_{k} J_{1}\left(\sqrt{\beta} r_{k}\right)-\sqrt{\beta} r_{0} J_{1}\left(\sqrt{\beta} r_{0}\right)\right]+ \\
& +\left[J_{0}\left(\sqrt{\beta} r_{k}\right)-J_{0}\left(\sqrt{\beta} r_{0}\right)\right] \cdot \\
& \left.\cdot\left[\sqrt{\beta} r_{k} Y_{1}\left(\sqrt{\beta} r_{k}\right)-\sqrt{\beta} r_{0} Y_{1}\left(\sqrt{\beta} r_{0}\right)\right]\right]^{-1}, \\
& C_{2}=C_{1} \frac{\alpha_{1}\left(1+\alpha_{1}\right)}{\alpha_{2}\left(2+\alpha_{1}\right)^{2}} \cdot \frac{1}{D} \cdot\left(\frac{\alpha_{2}\left(2+\alpha_{1}\right) D}{\alpha_{1}} r_{0}^{2}-\right. \\
& -\left(Y_{0}\left(\sqrt{\beta} r_{0}\right)-Y_{0}\left(\sqrt{\beta} r_{k}\right)\right) \cdot \sqrt{\beta} r_{0} J_{1}\left(\sqrt{\beta} r_{0}\right)- \\
& \left.-\left(J_{0}\left(\sqrt{\beta} r_{k}\right)-J_{0}\left(\sqrt{\beta} r_{0}\right)\right) \cdot \sqrt{\beta} r_{0} Y_{1}\left(\sqrt{\beta} r_{0}\right)\right) .
\end{aligned}
$$

For clarity, the results of the problem will be given below. The solution of differential equations (1) and (2) 
with boundary conditions (3), (4), (5) and (6) and the boundary contour in Figure 2, is defined by (38), (23), (14 ), (28), (41), (42), (26) and (27). The solution is:

$$
\begin{aligned}
& v(r)=\frac{C_{2}}{r}-C_{1} \frac{\alpha_{1}\left(1+\alpha_{1}\right)}{\alpha_{2}\left(2+\alpha_{1}\right)^{2}} . \\
& \frac{Y_{0}\left(\sqrt{\beta} r_{k}\right)-Y_{0}\left(\sqrt{\beta} r_{0}\right)}{D} \text {. } \\
& \cdot \sqrt{\beta} J_{1}(\sqrt{\beta} r)-C_{1} \frac{\alpha_{1}\left(1+\alpha_{1}\right)}{\alpha_{2}\left(2+\alpha_{1}\right)^{2}} \\
& \frac{J_{0}\left(\sqrt{\beta} r_{0}\right)-J_{0}\left(\sqrt{\beta} r_{k}\right)}{D} \text {. } \\
& \sqrt{\beta} Y_{1}(\sqrt{\beta} r)-C_{1} \frac{1+\alpha_{1}}{2+\alpha_{1}} r \\
& w(r)=C_{3} J_{0}(\sqrt{\beta} r)+C_{4} J_{0}(\sqrt{\beta} r)-C_{1} \frac{1+\alpha_{1}}{2+\alpha_{1}}, \\
& \beta=-\alpha_{2} \frac{2+\alpha_{1}}{1+\alpha_{1}} \\
& D=J_{0}\left(\sqrt{\beta} r_{0}\right) Y_{0}\left(\sqrt{\beta} r_{k}\right)- \\
& -J_{0}\left(\sqrt{\beta} r_{k}\right) Y_{0}\left(\sqrt{\beta} r_{0}\right) \text {, } \\
& C_{1}=\frac{r_{k}^{2} \omega \alpha_{2}\left(2+\alpha_{1}\right)^{2} D}{\alpha_{1}\left(1+\alpha_{1}\right)} \text {. } \\
& \left\{\frac{\alpha_{2}\left(2+\alpha_{1}\right) D}{\alpha_{1}}\left(r_{0}^{2}-r_{k}^{2}\right)+\right. \\
& +\left[Y_{0}\left(\sqrt{\beta} r_{0}\right)-Y_{0}\left(\sqrt{\beta} r_{k}\right)\right] \text {. } \\
& \cdot\left[\sqrt{\beta} r_{k} J_{1}\left(\sqrt{\beta} r_{k}\right)-\sqrt{\beta} r_{0} J_{1}\left(\sqrt{\beta} r_{0}\right)\right]+ \\
& \begin{array}{l}
+\left[J_{0}\left(\sqrt{\beta} r_{k}\right)-J_{0}\left(\sqrt{\beta} r_{0}\right)\right] \cdot\left(\sqrt{\beta} r_{k} Y_{1}\left(\sqrt{\beta} r_{k}\right)-\right]^{-1}, \\
\left.-\sqrt{\beta} r_{0} Y_{1}\left(\sqrt{\beta} r_{0}\right)\right)
\end{array} \\
& C_{2}=C_{1} \frac{\alpha_{1}\left(1+\alpha_{1}\right)}{\alpha_{2}\left(2+\alpha_{1}\right)^{2}} \cdot \frac{1}{D}\left\{\frac{\alpha_{2}\left(2+\alpha_{1}\right) D}{\alpha_{1}} r_{0}^{2}-\right. \\
& -\left[Y_{0}\left(\sqrt{\beta} r_{0}\right)-Y_{0}\left(\sqrt{\beta} r_{k}\right)\right] \cdot \sqrt{\beta} r_{0} J_{1}\left(\sqrt{\beta} r_{0}\right)-\left(J_{0}\left(\sqrt{\beta} r_{k}\right)\right. \\
& \left.-J_{0}\left(\sqrt{\beta} r_{0}\right) \cdot \sqrt{\beta} r_{0} Y_{1}\left(\sqrt{\beta} r_{0}\right)\right\} \text {, } \\
& C_{3}=C_{1} \frac{1+\alpha_{1}}{2+\alpha_{1}} \cdot \frac{Y_{0}\left(\sqrt{\beta} r_{k}\right)-Y_{0}\left(\sqrt{\beta} r_{0}\right)}{D}, \\
& C_{4}=C_{1} \frac{1+\alpha_{1}}{2+\alpha_{1}} \cdot \frac{J_{0}\left(\sqrt{\beta} r_{0}\right)-J_{0}\left(\sqrt{\beta} r_{k}\right)}{D} .
\end{aligned}
$$

\section{RESULTS AND DISCUSSION}

In order to provide a concrete example to illustrate the graphs of functions (v) and (w), it will be adopted that:

$$
\begin{aligned}
& \alpha_{1}=10 \\
& \alpha_{2}=10 \\
& r_{0}=0.004 m \\
& r_{k}=0.0048 m
\end{aligned}
$$

$$
\omega=100 s^{-1}
$$

The values of functions $(v)$ and $(w)$ were calculated in the range from $\left(r_{0}=0.004\right)$ to $\left(r_{k}=0.0048\right)$ with a step of ( $\Delta=0.00008$ ), using a specially made program to calculate the Bessel functions in the program language FORTRAN. The graphs are presented on Figures 3 and 4.

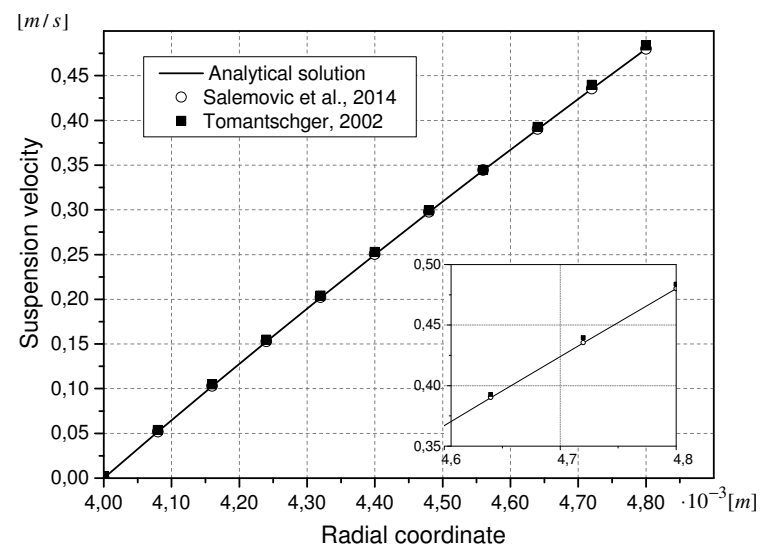

Figure 3. The chart of value $v(r)$ depending on the radial coordinate $(\mathbf{r})$

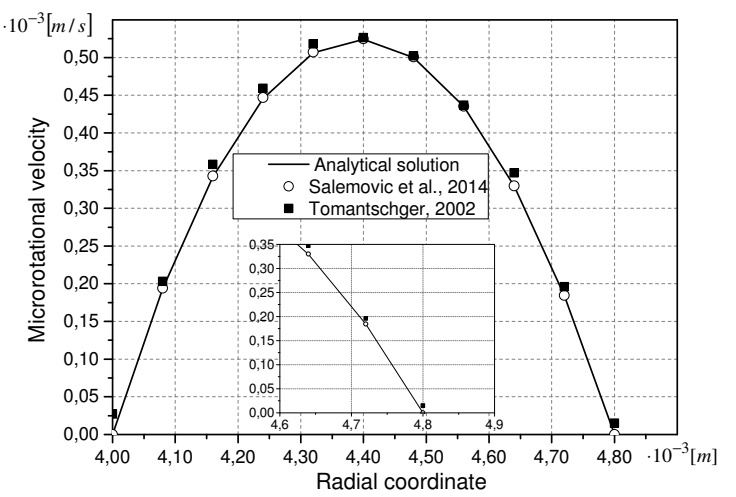

Figure 4. The chart of value $w(r)$ depending on the radial coordinate $(r)$

The analysis of Figure 4 reveals that the microrotational velocity $(w)$ is an approximately parabolic function that reaches its peak in the middle of the considered interval for the radial coordinate $(r)$. Also, the microrotational velocities $(w)$ at the outer surface of the inner cylinder and the inner surface of the outer cylinder are zero. This is logical and expectable according to the physical reality of the problem. This served as a verification of the analytical solution of the proposed mathematical model expressed through equations (1) and (2).

In the paper [16], the author postulated the solution of coupled differential equations (1) and (2) in the form of an infinite mathematical order, introducing the MacDonald function and modified Bessel functions of the second kind of zero and the first order. The final results (Figures 3 and 4) showed good agreement with the solution given by expressions (43)-(50). Also, quite good agreement was achieved with the results of numerical procedure of the same problem given in [17]. The difference between the calculated analytical and numerical values is less than $0.39 \%$ for $v(r)$, and less than $0.36 \%$ for $w(r)$. The numerical problem, given in [17], was solved by applying the method of finite differences and the reduction of the order of equations. 


\section{CONCLUSION}

The results of the analytical procedure of solving the system of differential equations (1) and (2) that are shown in the graphs (Figures 3 and 4) revealed excellent accuracy and agreement with the expected behavior of the suspension. Analytical expressions (43) and (44) enable us to determine the suspension velocity (v) and the microrotational velocity $(\mathrm{w})$ at each point along the radial coordinate (r). This is of particular significance for the practice because the knowledge of these speeds can be used to influence a better mixing of the phases and creation of a homogeneous suspension.

Further research is supposed to determine the numerical solution of differential equations (1) and (2) with the application of the method of finite elementary volume, and verify the compliance of the obtained results with analytical expressions (43) and (44) for some characteristic values of the radial coordinate (r).

\section{REFERENCES:}

[1] Eringen, A.C.: Simple micro fluids, International Journal of Engineering Science, Vol. 2, No.2, pp. 205-217, 1964.

[2] Eringen, A.C., and Suhubi, E.S.: Nonlinear theory of simple microelastic solids, International Journal of Engineering Science Vol. 2, No. 2, pp. 189-203, 1964.

[3] Lukaszewicz, G.: Micropolar Fluids: Theory and Applications, Birkhauser, Boston, 1999.

[4] Lukaszewicz, G.: Long Time Behavior of 2D Micropolar Fluid Flows, Mathematical and Computer Modelling, No. 34, pp. 487-509, 2001.

[5] Vernerey, F. and Chevalier, T.: A multiscale microcontinuum model to capture strain localization in composite materials, Journal for Multiscale Computational Engineering, Vol. 10, No. 5, pp. 487-501, 2012.

[6] Ahmadi, G.: A generalized continuum theory for multiphase suspension flows, International Journal of Engineering Science, Vol. 23, No.1, pp. 1-25, 1985.

[7] Cvetković, P.: The continuum theory applied to suspension flow, in: Proceedings of XVII Yugoslav Meeting of Theoretical and Applied Mechanics, 0307.7.1986, Zadar, pp. 125-131.

[8] Cvetković, P.: On hydrodynamics of mixtures with nonsymmetric stress tensor-the case of suspension flow, Bulletin of Applied Mathematics., Vol. 15, No. 6, pp. 627-635, 1989.

[9] Cvetković, P., Kuzmanović, D. and Golubović, Z.: Nonlocal equations of the greasing layer of suspension, Theoretical and Applied Mechanics, Vol. 19, pp. 9-22, 1993.

[10] Golubović, Z. and Cvetković, P.: On the principle of virtual work in the theory of immiscible mixtures containing Interface, Theoretical and Applied Mechanics, Vol. 15, pp. 31-43, 1989.

[11] Papautsky, I., Brazzle, J., Ameel, T. and Frazier, A.B.: Laminar fluid behavior in microchannels using micropolar fluid theory, Sensors and Actuators, No. 73, pp. 101-108, 1999.

[12]Hung K.Y, Hsu T.H. and Lin J.W.: Mixed convection of micropolar fluids in a vertical wavy channel saturated with porous media, Journal of Porous Media, Vol. 16, No. 12, pp. 1107-1118, 2013.

[13]Hung, K.Y, Hsu, T.H. and Lin, J.W.: Transient behavior of micropolar fluids through a porous wavy channel, Journal of Porous Media, Vol. 17, No. 1, pp. 1-15, 2014.

[14] Ramana Murthy, J.V., Srinivas, J. and Sai, K.S.: Flow of immiscible micropolar fluids between two porous beds, Journal of Porous Media, Vol. 17, No.4, pp. 287-300, 2014.

[15] Chen, J., Chen, Z.M. and Dong, B.Q.: Existence of $H^{2}$-global attractors of two-dimensional micropolar fluid flows, J. Math. Anal. Appl., No. 322, pp. 512$522,2006$.

[16] Tomantschger, K.W.: Series solutions of coupled diferential equations with one regular singular point, Journal of Computational and Applied Mathematics No. 140, pp. 773-783, 2002.

[17] Salemović, D., Dedić, A., Jovanović B.: A numerical solution of differential equations of the flow of suspension between two coaxial cylinders, in: Proceedings of $10^{\text {th }}$ European Fluid Mechanics Conference, 14-18.9.2014, Copenhagen, 13pp. (without pagination on $\mathrm{CD}$ )

\section{NOMENCLATURE}

$$
\begin{array}{ll}
v(r) & \text { suspension velocity }[\mathrm{m} / \mathrm{s}] \\
w(r) & \text { microrotational velocity[m/s] } \\
r & \text { radial coordinate }[\mathrm{m}]
\end{array}
$$

\section{Greek symbols}

$$
\begin{array}{ll}
\alpha_{1} & \text { constant } \\
\alpha_{2} & \text { constant } \\
\beta & \text { constant } \\
\omega & \text { angular velocity of external cylinder }\left[\mathrm{s}^{-1}\right]
\end{array}
$$

\section{Superscripts}

$\begin{array}{ll}o & \text { Initial } \\ k & \text { final }\end{array}$

\section{ПРИМЕНА ТЕОРИЈЕ МИКРОПОЛАРНОГ КОНТИНУМА НА СТРУЈАЊЕ СУСПЕНЗИЈЕ У ЦИЛИНДРИЧНОМ КАНАЛУ}

\section{А. Дедић, Д. Салемовић, Б. Јовановић}

У раду је представљено аналитичко решење математичког модела који описује струјање суспензије у цилиндричном каналу. Математички модел је примена теорије микрополарног континума и састоји се од спрегнутог система диференцијалних 
једначина са променљивим коефицијентима. Цилиндрични канал сачињавају два саосна цилиндра, од којих унутрашњи мирује, а спољашњи ротира константном угаоном брзином. Овакав физички модел омогућава анализу струјања суспензије, као хетерогене мешавине течности и честица које се налазе у њој. Решење овог система једначина пронађено је у форми специјалних Беселових функција нултог и првог реда. Резултати аналитичког поступка су приказани графички за неке конкретне карактеристичне вредност, и показано је добро слагање резултата добијених аналитичким поступком са очекиваним. 